\title{
Pola Pemanfaatan Ruang pada Usaha Berbasis Rumah (UBR) di Klaster Batik Jenggot Kota Pekalongan
}

\author{
Arisngatiasih 1 \\ PT. Asca Hamoghasida Semarang \\ Jawa Tengah, Indonesia
}

Mohammad Muktiali

Jurusan Perencanaan Wilayah dan Kota

Universitas Diponegoro, Semarang

Artikel Masuk : 16 Oktober 2015

Artikel Diterima : 24 November 2015

Tersedia Online : 30 Desember 2015

\begin{abstract}
Abstrak: Kota Pekalongan adalah kota yang memiliki industri batik yang berkembang cukup pesat. Klaster Batik Jenggot adalah tiga klaster yang memiliki pertumbuhan terbaik dari 11 klaster batik di Kota Pekalongan. Usaha Berbasis Rumah (UBR) merupakan usaha yang dapat memberikan kontribusi tinggi dalam struktur ekonomi Kota Pekalongan melalui pemanfaatan rumah sebagai tempat usaha. Namun begitu, UBR di Klaster Batik Jenggot dihadapkan pada permasalahan ketidakjelasan batasan pemanfaatan ruang rumah sebagai tempat usaha sekaligus sebagai hunian. Tujuan penelitian adalah untuk mengkaji pola pemanfaatan ruang rumah dengan adanya UBR di Klaster Batik Jenggot. Penelitian dilakukan dengan metode penelitian kualitatif. Sampel diambil dengan teknik snowball sampling dengan jumlah sampel 9 responden. Analisis dilakukan dengan teknik analisis deskriptif kualitatif. Hasil penelitian menunjukkan bahwa pola pemanfaatan ruang pada rumah untuk aktivitas mencetak batik diklasifikasikan menjadi dua tipologi, yaitu tipologi campuran dan tipologi terpisah. Pada tipologi ruang rumah campuran, pemanfaatan ruang pada bangunan induk sebagai tempat tinggal bercampur fungsinya sebagai tempat kerja, dimana aktivitas cetak biasanya dilakukan di bagian luar rumah. Sedangkan pada tipologi ruang rumah terpisah, menyediakan ruang kerja di samping, di belakang dan di depan bangunan induk sedangkan untuk aktivitas rumah tangga masih berlangsung di dalam bangunan induk. Pemanfaatan ruang-ruang rumah pada UBR disesuaikan dengan jenis dan waktu aktivitas.
\end{abstract}

Kata kunci: pemanfaatan ruang rumah, tipologi rumah, UBR

Abstract: Pekalongan is a city where batik industry grows rapidly. Jenggot Batik Cluster is ranked at the top three of the 11 batik clusters in Pekalongan City. Home Based Enterprise $(H B E)$ is a kind of business activity which highly contributes to the local economy through housing utilization as a business making a place. However, the HBEs in the Jenggot Batik Cluster are facing problems when the functioning of the house is not clearly separated

\footnotetext{
${ }^{1}$ Korespondensi Penulis: PT. Asca Hamoghasida Semarang, Indonesia Email: aris_ngatiasih@yahoo.com
} 


\section{Pola Pemanfaatan Ruang pada Usaha Berbasis Rumah (UBR) di Klaster Batik Jenggot ...}

between the shelter and business utilities. The aim of this research is to examine the pattern of in-house space utilization of the HBEs in the Jenggot Batik Cluster. The study conducts qualitative research method to draw an inference from selected nine respondents taken from snowball sampling technique. The analysis is completed by using qualitative descriptive analysis. The results show that the pattern of in-house space utilization for batik printing activities is classified into mixed and separated uses. The former type features a mixed use of shelter and business functions where the business activity is undertaken in the outer part of the house. The separated type provides a clearer space functioning where the working space may locate separately on the front, in-between, or back of the main building. The space utilization in the HBEs relies on the types and working hours of the batik activities.

Keywords: housing space utilization, housing typology, $H B E$

\section{Pendahuluan}

Rumah dapat menjadi "modal” kerja yang handal dalam mengembangkan kekuatan ekonomi keluarga melalui Usaha Berbasis Rumah (Silas dalam Wibisono, 2013). Sama halnya ungkapan dari Lipton dalam Tipple (2000) yang mengungkapkan bahwa sumber daya yang ada di dalam rumah adalah uang (money), waktu (time) dan ruang (space). Sebuah rumah yang menjadi basis usaha perekonomian akan mengalami penyesuaian dengan semakin bertambahnya kebutuhan sejalan dengan fungsinya sebagai "modal". Rumah tinggal yang mengalami perubahan fungsi, akibat pengaruh usaha atau ekonomi disebut sebagai rumah produktif. Fungsi rumah tersebut harus dapat menampung dua kegiatan yang bebeda antara lain kegiatan berumah tangga dan kegiatan produksi. Hal ini diperjelas oleh Silas (2000) yang menyatakan bahwa rumah dalam fungsinya, dibagi dalam dua katagori, yaitu rumah yang dipergunakan sebagai tempat tinggal tanpa kegiatan lain dan rumah yang digunakan untuk usaha atau kegiatan ekonomi.

Home Base Enterprises ( $H B E \mathrm{~s}$ ) adalah kegiatan usaha rumah tangga yang merupakan kegiatan ekonomi rakyat yang dijalankan oleh keluarga, kegiatannya bersifat fleksibel, tidak terikat oleh aturan-aturan yang berlaku umum termasuk jam kerja yang dapat diatur sendiri, hubungan yang longgar antar modal dengan tempat usaha. Silas (2000) menegaskan bahwa dalam UBR yang berorientasi kepada produksi terdapat 3 (tiga) unsur pokok atau tahapan yang menjadi inti dari kegiatan UBR, yaitu penyiapan dan penyimpanan bahan baku, proses produksi, dan penyimpanan hasil.

Lebih lanjut, Tipple (2005) dalam penelitiannya di Surabaya mengemukakan bahwa kendala utama UBR adalah adanya persaingan ruang untuk usaha dengan ruang domestik. Persaingan penggunaan ruang dan sumber daya juga tercermin dalam perumahan produktif olahan hasil laut. Persaingan ruang dalam UBR dapat berupa konflik ruang dan multi-use space. Bukan persaingan penggunaan ruang dalam hunian saja yang terjadi namun juga adanya persaingan penggunaan ruang luar. Batas-batas penggunaan ruang sebagai ruang produksi semakin tidak jelas antara produsen satu dengan lainnya. Dari hal tersebut terlihat bahwa jenis produksi pada rumah produktif mempengaruhi kompleksitas tatanan serta pembagian ruang. Persaingan atau konflik ruang sekecil apapun akan sangat kritis akibatnya bagi tingkat kenyamanan (Tipple, 2004). Dengan adanya Home Based Enterprises, ruang-ruang domestik menjadi berkurang karena memang keinginan keluarga untuk meningkatkan penghasilan melalui HBE sehingga perlu diadakan upgrading kualitas permukiman (Tipple, 2004). Strassman (1987) mengasumsikan bahwa keadaan perumahan dapat menjadi lebih buruk tanpa adanya usaha berbasis rumah tangga.

Kegiatan industri batik di Klaster Jenggot hampir seluruhnya menggunakan rumah sebagai aktivitas kegiatan usaha pembatikan sehingga memberikan banyak peluang bagi masyarakat untuk mengembangkan usaha dan meningkatkan ekonomi. Hal ini sesuai 
dengan teori yang dikemukakan Turner (1972) bahwa aktivitas maksimal dapat dicapai dalam fungsi rumah tangga dan terkait dengan perubahan tingkat pendapatan ekonomi. Konsep ini disebut sebagai "Housing is a Process" yang melandasi tiga hal penting, yaitu nilai rumah, fungsi ekonomi, dan wewenang atas rumah. Dengan demikian, rumah dapat difungsikan sebagai penopang perekonomian pengrajin batik bahkan di Kota Pekalongan Usaha Berbasis Rumah (UBR) merupakan usaha yang memanfaatkan rumah yang memberikan kontribusi tinggi dalam struktur ekonomi Kota Pekalongan.

Pemanfaatan ruang rumah di klaster batik Jenggot adalah untuk melakukan produksi batik. Pemanfaatan ruang tersebut adalah ruang pada rumah baik ruang pada bangunan induk maupun ruang pada sekitarnya (halaman). Permasalahan umum yang terjadi pada Usaha Berbasis Rumah (UBR) adalah permasalahan pemanfaatan ruang pada rumah. Keterbatasan ruang untuk kegiatan usaha mengakibatkan masyarakat harus menggunakan rumah sebagai tempat usaha sekalipun sebagai tempat hunian tanpa ada batasan yang jelas. Padahal, rumah memiliki fungsi utama sebagai tempat tinggal dan tempat pembinaan keluarga, namun kondisi berbeda terjadi pada rumah yang juga digunakan sebagai tempat usaha di Klaster Jenggot. Di sisi lain penggunaan ruang oleh pelaku usaha berbasis rumah ini juga dikaitkan dengan tingkat pendapatan dari penghuni rumah itu sendiri karena pendapatan rumah tangga akan tergantung pada seberapa besar alokasi ruang rumah untuk kegiatan usaha, alokasi ruang mencetak batik yang memanfaatkan ruang halaman, sehingga perlu adanya alokasi ruang pada usaha rumah yang sesuai dan seimbang antara rumah untuk hunian dan untuk usaha. Hal ini menunjukkan bahwa ruang rumah dapat dimanfaatkan sebagai shared space. Ruang bersama atau shared space merupakan ruang untuk berbagi bersama yang biasanya digunakan sebagai interaksi antara anggota suatu komunitas, dimana dapat menimbulkan kebersamaan atau keguyuban (Indeswari, Antariksa, Pangarsa, \& Wulandari, 2013).

Dengan demikian, pemanfaatan sumber daya pada rumah sangat penting untuk kegiatan Usaha Berbasis Rumah (UBR). Hal ini dikarenakan usaha batik di Klaster Jenggot bertumpu pada rumah. Besar atau tidaknya pemanfaatan ruang pada rumah tergantung dari jumlah produksi batik yang akan dihasilkan. Pemanfaatan ruang pada rumah untuk kegiatan usaha agar masyarakat dapat mendapatkan keuntungan dari usaha tersebut, sehingga rumah sebagai tempat hunian sekaligus dapat digunakan sebagai sumber mata pencaharian atau sumber pendapatan. Dari rumusan masalah di atas, tujuan penelitian adalah untuk mengkaji pola pemanfaatan ruang rumah dengan adanya Usaha Berbasis Rumah (UBR) di Klaster Batik Jenggot.

\section{Metode Penelitian}

Metode yang digunakan dalam penelitian adalah metode penelitian kualitatif. Metode penelitian kualitatif juga sering disebut sebagai penelitian naturalistik karena penelitiannya dilakukan pada kondisi yang alamiah dan data yang terkumpul dan analisisnya lebih bersifat kualitatif. Pendekatan kualitatif dilakukan dengan mengeksplorasi dan memahami makna yang bersumber dari kata-kata dan tindakan (Moleong, 2006).

Pengumpulan data dilakukan dengan menggunakan dua metode, yaitu metode pengumpulan data primer dan sekunder. Metode pengumpulan data primer adalah pengumpulan data primer bertujuan untuk mengetetahui pemanfaatan ruang rumah terkait dengan pengrajin batik dalam kegiatan produksi batik melalui teknik wawancara dan observasi lapangan. Wawancara dilakukan ke masyarakat yang melakukan kegiatan pembatikan baik batik printing atau sablon, batik cap maupun batik abstrak yang berada di Klaster batik Jenggot. Sedangkan observasi lapangan membantu dalam memperoleh gambaran lebih jelas mengenai aktivitas produksi pembatikan yang dilakukan pengrajin. Sementara itu, metode pengumpulan data sekunder dilakukan dengan kajian literatur dan 
telaah dokumen melalui telaah terhadap Peta kawasan studi, demografi dan sebagainya dari hasil survey pada instansi terkait, seperti Bappeda Kota Pekalongan, BPS Kota Pekalongan, Dinas perindustrian dan Perdagangan.

Pengambilan sampel dilakukan melalui teknik non random sampling dengan bola salju menggelinding (snowballing). Penarikan sampel bola salju diawali dengan penentuan sampel pertama. Sampel berikutnya ditentukan oleh informasi sampel pertama dan demikian seterusnya. Melalui teknik pengambilan sampel ini, secara teoritis peneliti akan menghadapi sampel yang tidak terhingga.

\section{Gambaran Umum}

Wilayah studi dalam penelitian ini dilakukan di Kelurahan Jenggot, Kecamatan Pekalongan Selatan, Kota Pekalongan (lihat Gambar 1). Kelurahan Jenggot terbentuk sejak tahun 1990 dengan mayoritas penduduk bekerja di bidang batik dan masuk dalam wilayah klaster batik. Kelurahan Jenggot memiliki luas wilayah 123.500 Ha dengan batas wilayah sebagai berikut:

Sebelah utara : Kelurahan Medono

Sebelah selatan : Desa Simbang Wetan

Sebelah barat : Kelurahan Kradenan

Sebelah Timur : Kelurahan Kuripan Lor (Sungai Kupang)

Kelurahan Jenggot memiliki 11 RW dan 44 RT. Berdasarkan data Monografi Kelurahan Jenggot tahun 2014, jumlah penduduk di tahun 2014 sebanyak 11.661 jiwa dengan jumlah kepala keluarga sebanyak $2.975 \mathrm{KK}$ dan kepadatan penduduk sebesar 9.823 jiwa $/ \mathrm{km}^{2}$. Jumlah usia produktif pada kelompok usia 15-64 tahun di Kelurahan Jenggot sampai pertengahan tahun 2014 mencapai 7.500 jiwa atau 64,3\%. Sedangkan usia $0-14$ tahun sebesar 3.547 jiwa atau 30,6\%. Data Monografi Kelurahan Jenggot hingga pertengahan tahun 2014 juga menunjukkan bahwa sebanyak $1.378 \mathrm{KK}$ tergolong keluarga miskin atau sebanyak 5.333 jiwa (46,73\%) adalah penduduk miskin dengan rata-rata Upah Minimun Regional (UMR) sebesar Rp. 30.000,- per hari.

Jenis industri yang berkembang di wilayah studi merupakan industri yang berbasis industri rumahan, khususnya industri batik. Pengusaha maupun pengerajin batik terkonsentrasi di wilayah ini, yaitu pada klaster batik di Kel. Jenggot. Klaster batik di wilayah studi rata-rata menghasilkan batik sablon/printing, lilin, batik cap dan batik kontemporer/abstrak. Jenis produknya adalah seprei, daster, kaos, kain batik, baju dll. Industri yang ada bekembang dengan baik baik industri kecil, sedang dan besar. Berdasarkan data dari Dinas Perindustrian dan Perdagangan Kota Pekalongan Tahun 2013, jumlah industri kecil dan menengah di semua bidang di Kelurahan Jenggot mencapai 324 usaha, sedangkan usaha yang bergerak khusus di bidang batik mencapai 231 industri $(71,29 \%)$, baik berupa industri rumah tangga, industri kecil maupun industri sedang. Gambar 2 menunjukkan jumlah industri di Kelurahan Jenggot. 


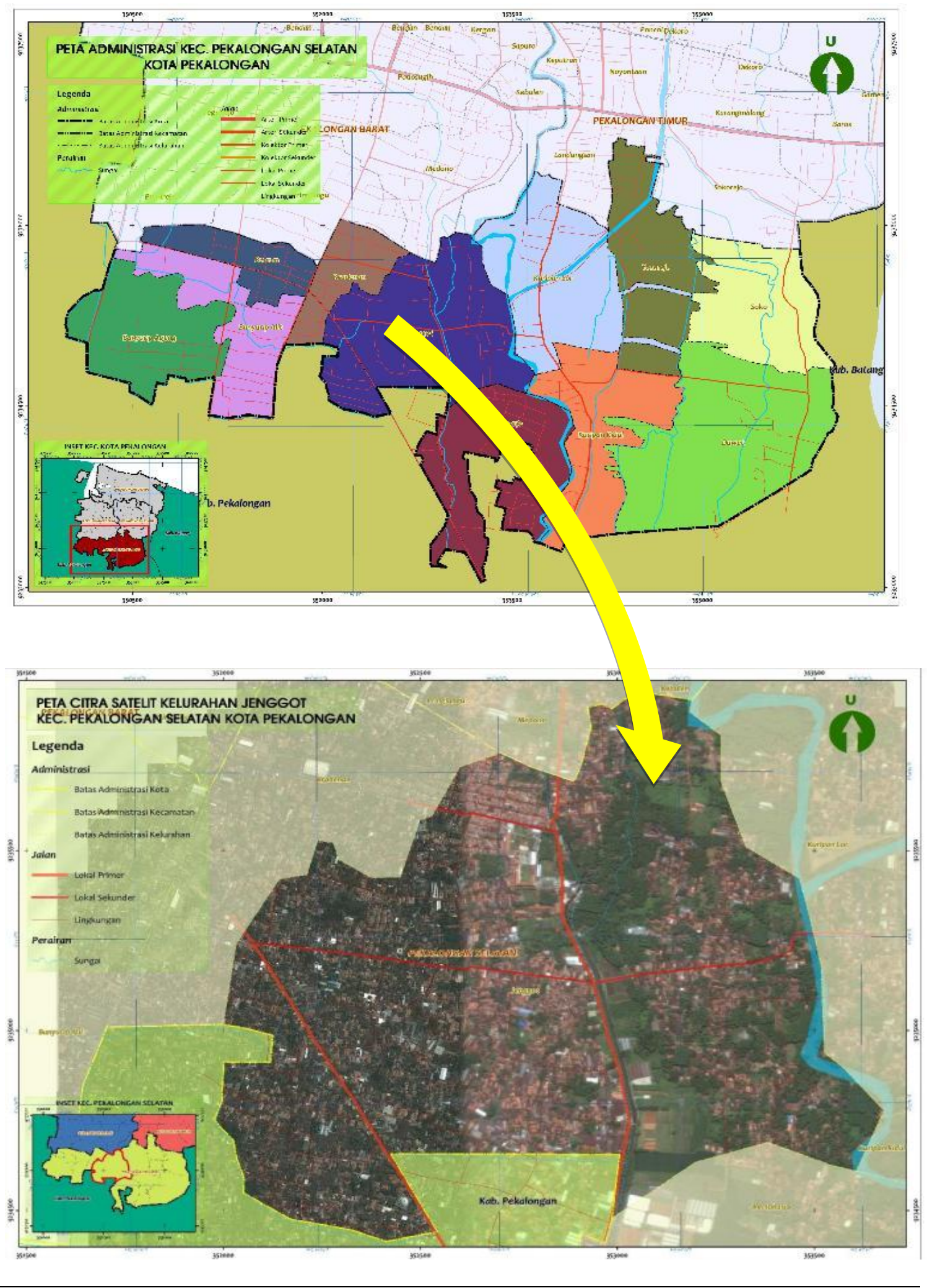

Gambar 1. Orientasi Wilayah Studi 


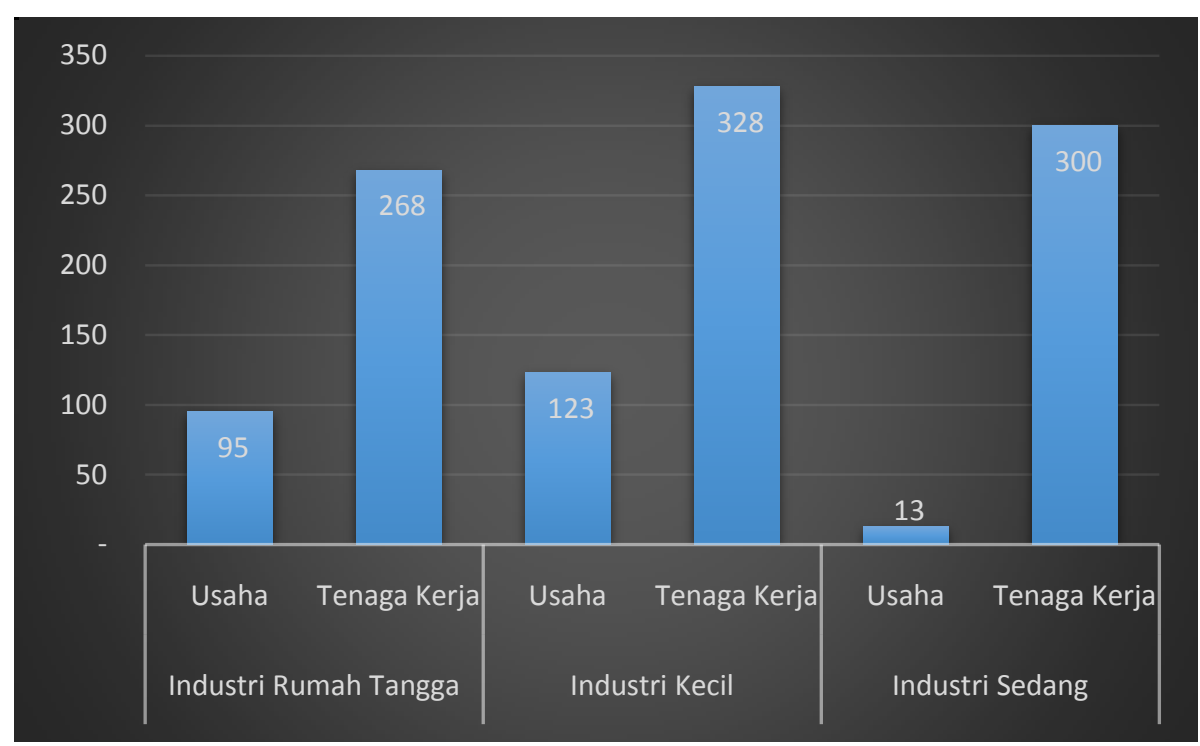

Sumber: Dinas Perindustrian \& Perdagangan Kota Pekalongan, 2013

Gambar 2. Jumlah Industri di Kelurahan Jenggot Tahun 2013 (Unit)

Analisis Pola Pemanfaatan Ruang pada Usaha Berbasis Rumah (UBR)

Analisis Karakteristik Klaster Batik Jenggot

\section{Identifikasi Karakteristik Jenis Usaha}

Pada dasarnya di klaster batik Jenggot terdapat 3 (tiga) jenis produksi kain batik, yaitu batik cap, batik printing dan batik abstrak. Setiap tahapan produksi pada masingmasing jenis batik berbeda. Pengusaha batik yang ada di klaster batik Jenggot merupakan jenis industri mikro, kecil dan sedang. Namun demikian, untuk industri mikro dan kecil rata-rata memproduksi batik sablon, abstrak, dan cap model batik abstrak adalah yang paling diminati. Hal ini dikarenakan alternatif warnya yang beragam, teknik yang mudah dan tidak terlalu banyak memanfaatkan ruang.

\section{Identifikasi Karakteristik Input Produksi}

Input untuk proses produksi adalah bahan baku dalam proses produksi batik bahan baku utamanya adalah kain mori, lilin/malam dan zat pewarna. Berikut penjelasannya:

a. Bahan Baku dan Penunjang

Bahan baku utama dalam industri batik adalah kain mori (kain katun putih) dan zat pewarna. Bahan baku kain mori didapatkan di pusat Kota Pekalongan karena pada Klaster Batik Jenggot belum terdapat toko yang menjual bahan baku tersebut. Kebutuhan bahan baku dipasok oleh pedagang kain dan tekstil di daerah Pekalongan, Bandung, dan Solo. Untuk ketersediaan bahan baku utama, yaitu kain mori masih dapat disediakan oleh pedagang. Namun, untuk bahan seperti pewarna, masih kurang karena sering terjadi kelangkaan bahan pewarna dikarenakan bahan zat pewarna masih didatangkan secara import. Kondisi ini akhirnya menghambat proses produksi serta menjadikan harga tidak stabil. 


\section{b. Tenaga Kerja}

Jumlah tenaga kerja setiap pengrajin berbeda-beda, yaitu antara 2 hingga 20 orang. Pengrajin dengan tenaga kerja banyak adalah pengrajin dengan usaha hulu hilir. Sedangkan pengrajing batik dengan sistem babar memiliki jumlah tenaga kerja antara 2 hingga 10 orang. Namun demikian, hampir seluruh pengrajin di Klaster Batik Jenggot memanfaatkan tenaga kerja di sekitar mereka, maupun yang memiliki ikatan saudara. Pemilihan tenaga kerja dengan cara demikian akan mempermudah hubungan kerja serta memberdayakan sumber daya di keluarga.

\section{Identifikasi Karakteristik Proses Produksi}

Proses produksi merupakan kegiatan yang dikerjakan segala sesuatu yang telah disiapkan pada tahap pra produksi, karena pada tahap ini adalah membuat bahan baku hingga menjadi bahan setengah jadi atau menjadi helaian kain batik. Proses produksi yang ada di klaster batik Jenggot adalah proses pembuatan kain mori menjadi kain batik yang siap dijahit. Saat permintaan pasar sedang sepi atau rendah, akan mempengaruhi tingkat produksi batik yang juga akan melemah sejalan dengan kondisi daya beli masyarakat. Namun saat permintaan tinggi, seperti saat mendekati hari raya, tingkat produksi juga akan meningkat.

Pada dasarnya di klaster batik Jenggot terdapat 3 (tiga) jenis produksi kain batik yaitu batik cap, batik printing dan batik abstrak. Setiap tahapan produksi pada masing-masing jenis batik berbeda. Dari masing-masing proses pembuatan batik maka jenis batik sablon, printing dan cap merupakan jenis batik yang membutuhkan ruang luas karena proses yang dilakukan banyak. Proses pembuatan batik sablon/ printing terlihat di Gambar 3.

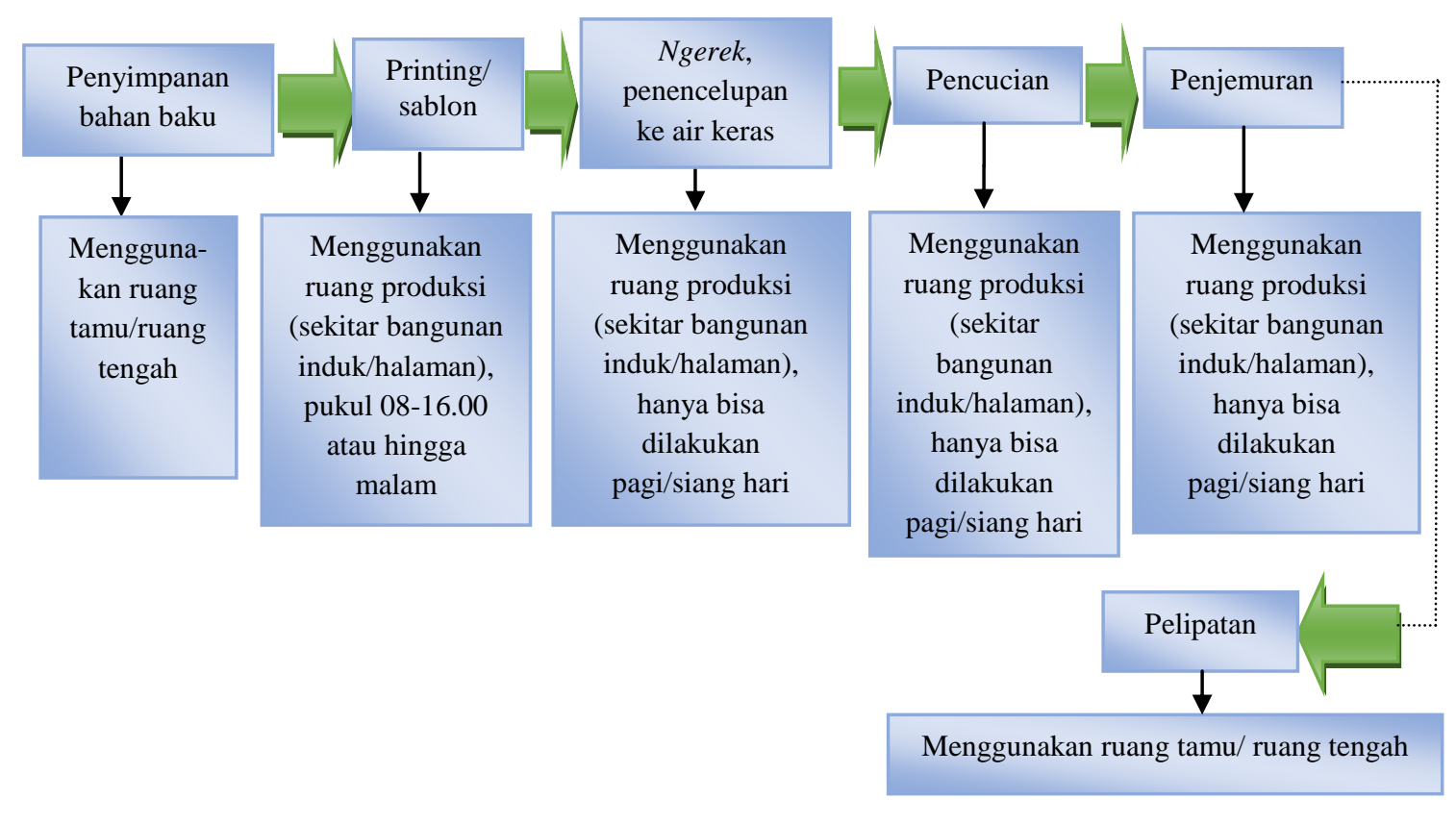

\section{Gambar 3. Proses Pembuatan Batik Sablon atau Printing}

Sedangkan model abstrak teknik colet membutuhkan ruang sedikit karena hanya terdapat dua proses yaitu mencolet (memberi warna pada pola dengan kuas) dan menjemur. Proses pembuatan batik colet terjelaskan di Gambar 4. 


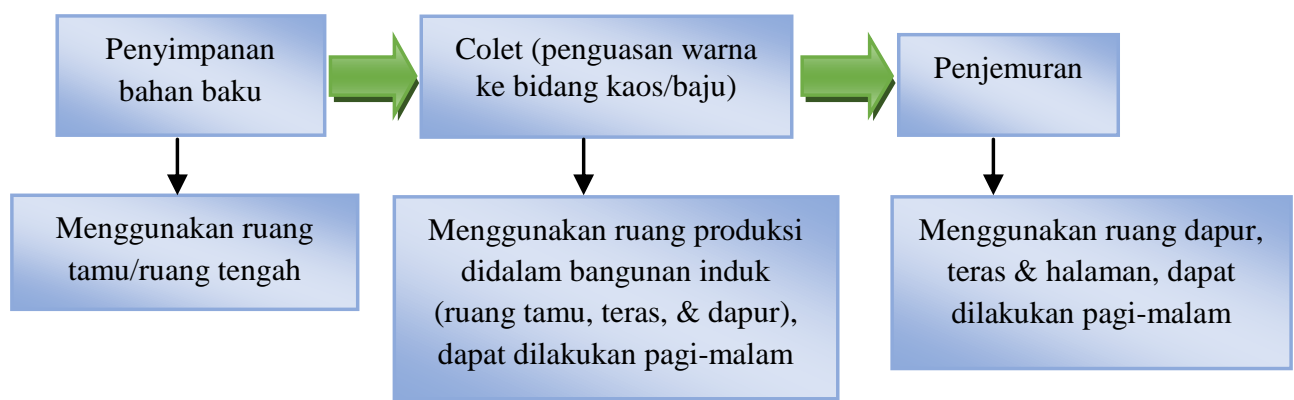

Gambar 4. Proses Pembuatan Batik Abstrak Model Colet

\section{Analisis Pemanfaatan Sumber Daya Dalam Rumah (Uang, Waktu dan Ruang)}

\section{Pemanfaatan Sumber Daya Uang(Money)}

Salah satu sumber daya yang ada di dalam rumah adalah uang (money), yaitu uang yang dapat digunakan didalam rumah yang nantinya dapat menghasilkan uang atau pendapatan. Modal awal biasanya digunakan untuk membuat tempat produksi dan alatalatnya, besar kecilnya tergantung dari seberapa besar ruang yang akan digunakan utnk proses produksi dan alat apa saja yang akan digunakan. Gambar 5 berikut menjelaskan sumber daya uang (money) yang ada dalam rumah.

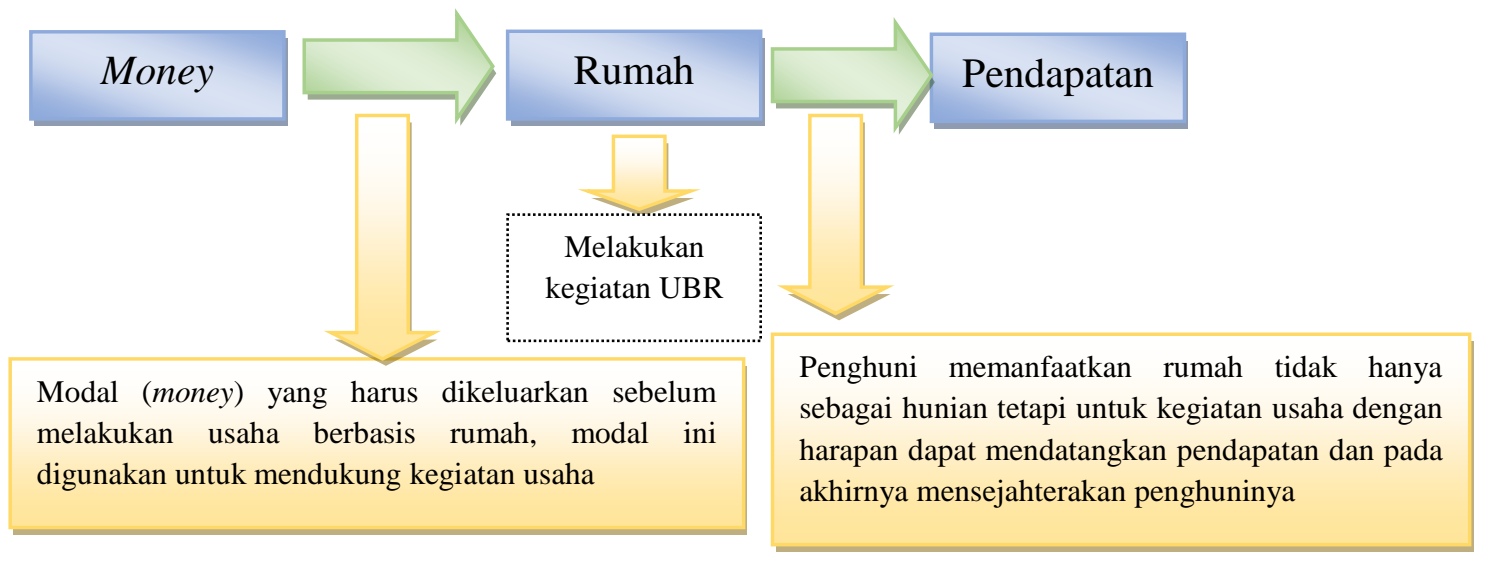

Gambar 5. Analisis Sumber Daya Money Dalam Rumah

\section{Pemanfaatan Sumber Daya Waktu (Time)}

Rata-rata pemanfaatan waktu (time) pada rumah untuk produksi adalah pukul 8.00 WIB sampai pukul 16.00 WIB. Sedangkan pada saat tertentu karena dipengaruhi oleh faktor ekternal, pemanfaatan rumah untuk produksi akan lebih lama yaitu sampai malam. Waktu lainnya seperti pada saat menjelang hari raya/lebaran pemanfaatan ruang rumah akan meningkat hingga $3 \mathrm{x}$ lipat dari pemanfaatan pada saat biasa. Hal ini dikarenakan produktivitas pembuatan batik juga ikut meningkat sehingga pada saat musim tersebut, seluruh ruangan yang ada di rumah maupun sekitar rumah akan penuh dengan kain batik. Dengan demikian, puncak pemanfaatan rumah untuk kegiatan usaha adalah berdasarkan waktu-waktu tertentu baik dipengaruhi oleh alam seperti waktu penghujan dan kemarau serta 
dipengaruhi oleh waktu-waktu momentum, seperti pada saat liburan maupun mendekatan hari raya idul fitri dan puasa.

\section{Pemanfaatan Sumber Daya Ruang (Space)}

Sumber daya utama yang terdapat dalam rumah ruang (space), yang dapat dimanfaatkan oleh penghuninya untuk berbagai aktivitas, setiap waktu dan tidak terbatas. Sehingga tidak heran apabila hampir seluruh pengrajin batik yang ada di Klaster Batik Jenggot memanfaatkan ruang yang ada di dalam rumah maupun ruang yang ada di luar rumah untuk aktivitas usaha (produksi). Selain dimanfaatkan untuk aktivitas hunian (hunian), rumah juga digunakan untuk aktivitas produksi dimana antara aktivitas produksi dan aktivitas hunian dapat dilakukan secara bersamaan tanpa harus mengorbankan salah satu aktivitas tersebut. Seluruh penghuni rumah dapat memanfaatkan ruang rumah baik di dalam maupun di luar rumah, baik untuk usaha produksi batik, bermain anak-anak dan kegiatan lainnya. Dengan demikian, terjadi pemanfaatan ganda ruang-ruang rumah dalam waktu dan ruang yang sama. Meskipun begitu, tidak terjadi konflik dalam pemanfaatan ruang rumah karena masing-masing individu dapat memahami kepentingan lainnya. Ini dikarenakan rumah juga digunakan sebagai tempat usaha produktif yang akan bermanfaat bagi kesejahteraan seluruh penghuni rumah.

Rata-rata pengrajin memanfaatkan ruang tamu, dimana ruang yang biasanya difungsikan sebagai ruang untuk menerima tamu, dimanfaatkan juga untuk aktivitas produksi yang biasanya untuk menyimpan kain mori, kain batik yang sudah jadi dan untuk packing/pelipatan kain. Sedangkan ruang yang digunakan untuk produksi utama pembatikan adalah ruang teras, ruang depan/halaman, ruang samping dan ruang belakang. Keseluruhan ruang tersebut berperan penting dalam proses produksi batik karena ruang-ruang tersebut digunakan untuk mencetak dan menjemur batik. Visualisasi pemanfaatan ruang hunian untuk proses produksi dan ruang hunian tergambarkan di Gambar 6.
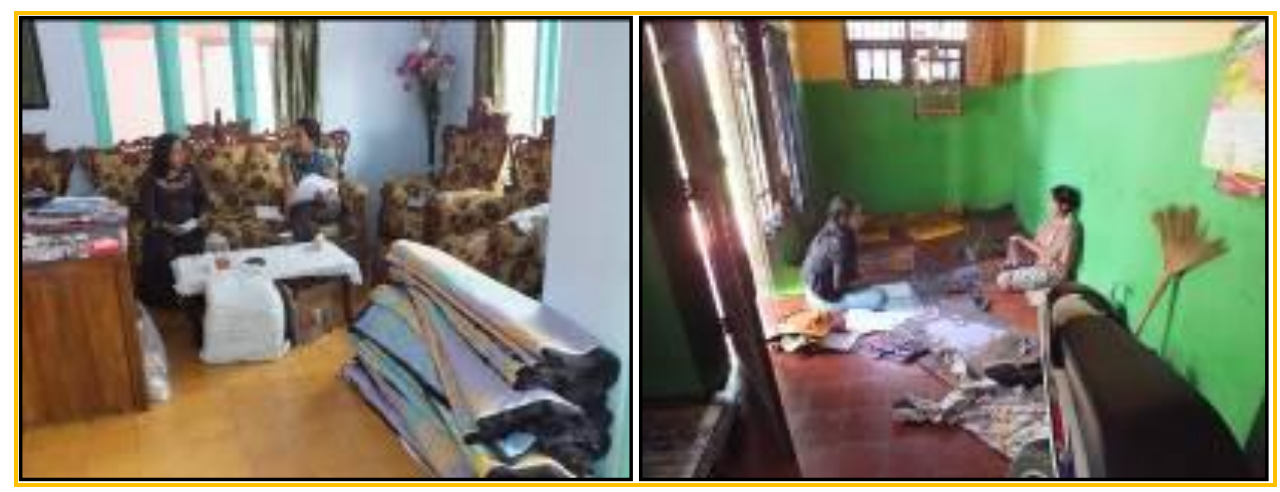

Gambar 6. Visualisasi Ruang Hunian dan Produksi

\section{Analisis Tipologi Pemanfaatan Ruang Rumah pada UBR}

Terdapat tiga sumber daya pada rumah yang dapat dimanfaatkan oleh pengguna rumah untuk kegiatan produksi atau usaha, yaitu sumber daya uang, waktu dan ruang. Adanya pemanfaatan ketiga sumber daya ini menjadikan munculnya tipologi pemanfaatan ruang rumah yang berbeda-beda pula. Untuk lebih jelasnya pemanfaatan sumber daya pada rumah yang dilakukan oleh pengrajin batik di klaster batik Jenggot adalah sebagai berikut: 


\section{Tipologi Pemanfaatan Ruang Rumah Campuran}

Tipologi ruang rumah campuran adalah tipe pemanfaatan ruang pada bangunan induk dimana fungsi bangunan induk sebagai tempat tinggal bercampur fungsinya sebagai tempat kerja, namun begitu fungsi bangunan induk sebagai tempat tinggal masih dominan. Adapun ruangan yang biasa dan sering digunakan sebagai tempat kerja adalah ruang keluarga, ruang tamu, ruang belakang, dapur, dan teras rumah. Proses cetak dilakukan di luar bangunan induk, seperti samping rumah, ataupun di belakang rumah dan untuk kegiatan penjemuran dilakukan disekitar bangunan induk. Adapun aktivitas cetak yang dilakukan di dalam bangunan induk adalah aktivitas pewarnaan colet dengan teknik sederhana. Gambar 7 memvisualisasikan kondisi pemanfaatan ruang rumah campuran.

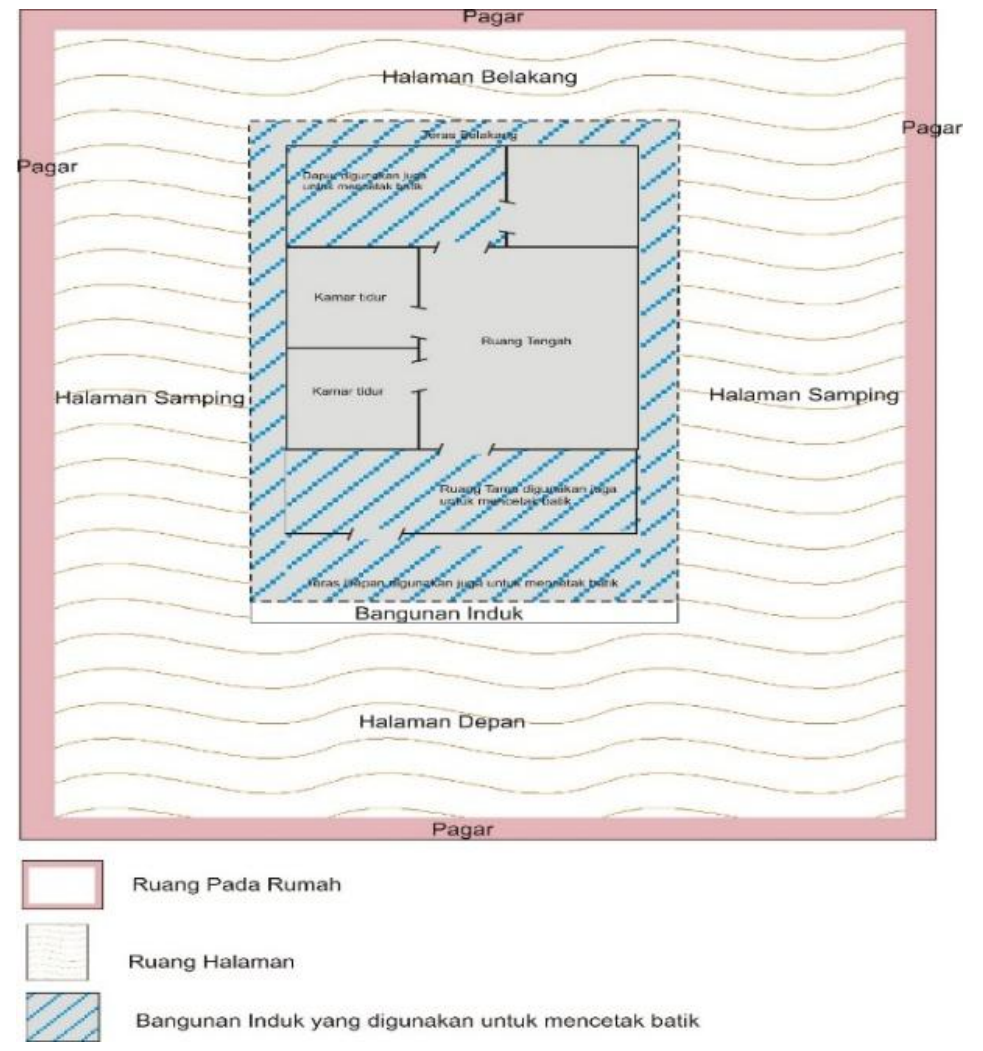

Gambar 7. Tipologi Pemanfaatan Ruang Rumah Campuran

\section{Tipologi Pemanfaatan Ruang Rumah Terpisah}

Tipologi ruang rumah terpisah adalah tipe rumah dengan aktivitas cetak berada di samping, di belakang dan di depan bangunan induk. Tipologi ruang rumah ini menyediakan ruang khusus cetak di belakang atau samping atau depan rumah yang menjadi bangunan induk sedangkan untuk aktivitas rumah tangga masih berlangsung di dalam bangunan induk. Pembuatan ruang kerja biasa dilakukan dengan membuat penyekat dari kayu sebagai pembatas antara ruang kerja dengan ruang hunian. Aktivitas cetak biasa berlangsung di pekarangan rumah, dimana $50 \%$ luas lahan pekarangan milik pengrajin biasa digunakan untuk kegiatan cetak. Ilustrasi pemanfaatan ruang rumah terpisah tergambarkan di Gambar 8. 


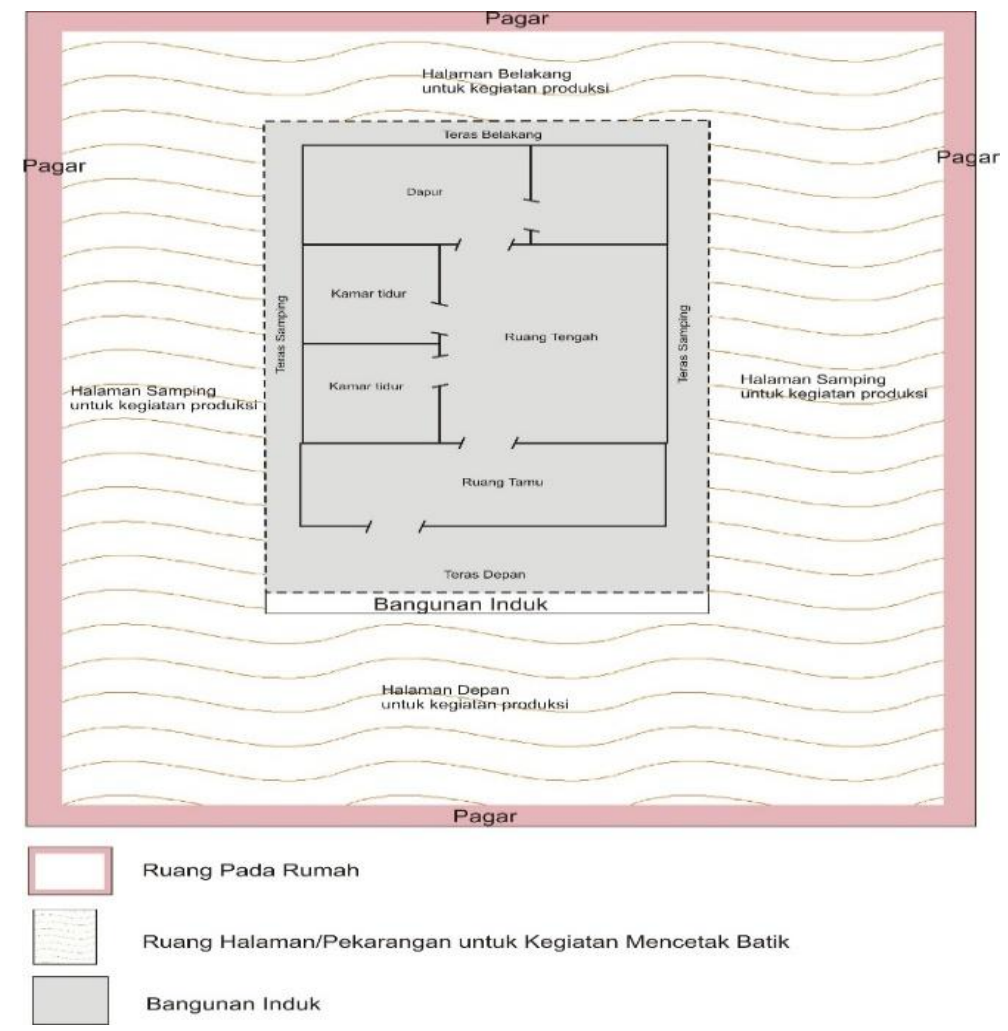

\section{Gambar 8. Tipologi Pemanfaatan Ruang Terpisah}

Jika diklasifikasikan maka pola pemanfaatan ruang rumah pada Klaster Batik Jenggot terlihat sebagaimana pada skema di Gambar 9.

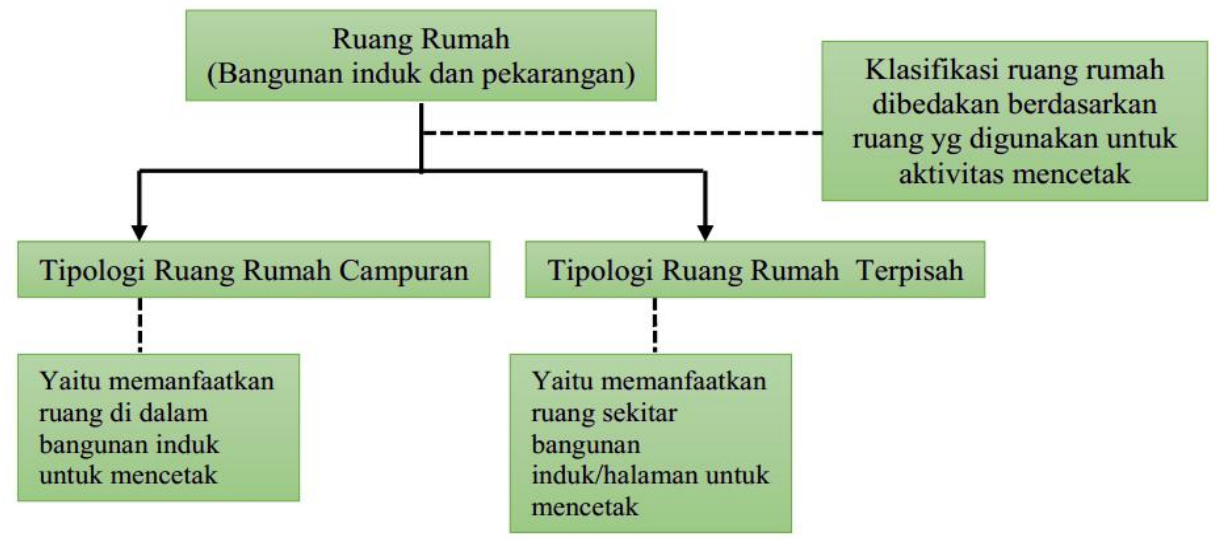

\section{Gambar 9. Klasifikasi Tipologi Pemanfaatan Ruang Rumah}

Berdasarkan klasifikasi tipologi pemanfaatan ruang rumah maka terdapat beberapa perbedaan antara tipologi pemanfaatan ruang rumah campuran maupun terpisah. Untuk lebih jelasnya dapat dilihat pada Tabel 1. 
Tabel 1. Sintesis Analisis Perbedaan Tipologi Ruang Rumah

\begin{tabular}{|c|c|c|c|}
\hline No & Karakteristik & $\begin{array}{l}\text { Tipologi Ruang Rumah } \\
\text { Campuran } \\
\end{array}$ & Tipologi Ruang Rumah Terpisah \\
\hline 1 & $\begin{array}{l}\text { Pemanfaatan sumber } \\
\text { daya ruang }\end{array}$ & $\begin{array}{l}\text { Memanfaatkan ruang rumah pada } \\
\text { bangunan induk untuk kegiatan } \\
\text { usaha }\end{array}$ & $\begin{array}{l}\text { Memanfaatkan ruang rumah sekitar } \\
\text { bangunan induk (halaman) } \\
\text { melakukan kegiatan usaha }\end{array}$ \\
\hline 2 & Teritori ruang rumah & $\begin{array}{l}\text { Tidak terdapat batas yang jelas } \\
\text { natara fungsi ruang rumah untuk } \\
\text { kegiatan hunian dengan kegiatan } \\
\text { produksi }\end{array}$ & $\begin{array}{l}\text { Sudah terdapat pembatas fungsi ruang } \\
\text { untuk hunian dan untuk kegiatan } \\
\text { produksi }\end{array}$ \\
\hline 3 & $\begin{array}{l}\text { Penyerapan Tenaga } \\
\text { Kerja }\end{array}$ & $\begin{array}{l}\text { Tenaga kerja hanya berasal dari } \\
\text { anggota keluarga. Jumlah tenaga } \\
\text { kerja hanya } 2-4 \text { orang }\end{array}$ & $\begin{array}{l}\text { Penyerapan tenaga kerja sudah diluar } \\
\text { anggota keluarga (teman, saudaran dan } \\
\text { tetangga). Jumlah tenaga kerja } 4-25 \\
\text { orang }\end{array}$ \\
\hline 4 & $\begin{array}{l}\text { Pemanfaatan sumber } \\
\text { daya uang }\end{array}$ & $\begin{array}{l}\text { Uang awal untuk usaha masih } \\
\text { dibawah } 5 \text { juta rupiah, sedangkan } \\
\text { uang yang harus dikeluarkan } \\
\text { untuk biaya produksi sekitar } 1-3 \\
\text { juta/bulan }\end{array}$ & $\begin{array}{l}\text { Uang awal yang harus dikeluarkan } \\
\text { untuk kegiatan produksi diatas } 10 \text { juta } \\
\text { rupiah sedangkan uang yang harus } \\
\text { dikeluarkan setiap bulannya untuk } \\
\text { kegiatan produksi 5-600 juta rupiah }\end{array}$ \\
\hline 5 & Produksi batik & $\begin{array}{l}\text { Dapat menghasilkan batik } 40-100 \\
\text { kodi/bulan }\end{array}$ & $\begin{array}{l}\text { Dapat mengahasilkan batik antara 500- } \\
3.000 \mathrm{kodi} / \mathrm{bulan}\end{array}$ \\
\hline 6 & Keuntungan & $\begin{array}{l}\text { Keuntungan yang didapat } \\
\text { pengrajin } 400 \mathrm{ribu}-2 \text { juta rupiah }\end{array}$ & $\begin{array}{l}\text { Keuntungan yang yang didapat sekitar } \\
3 \text { juta }-1 \text { milyar rupiah/bulan }\end{array}$ \\
\hline
\end{tabular}

\section{Keterkaitaan Antara Tipologi Rumah Dengan Pemanfaatan Sumber Daya Rumah Lainnya}

Pemanfaatan sumberdaya ruang (space) yang sudah digambarkan melalui tipologi pemanfaatan ruang rumah baik campuran maupun terpisah ternyata juga akan mempengaruhi pemanfaatan sumberdaya lainnya. Pada tipologi pemanfaatan ruang rumah campuran akan memanfaatkan sumberdaya uang lebih sedikit dibandingkan dengan tipologi ruang rumah terpisah, pemanfaatan waktu pada tipologi ruang rumah campuran maupun tipologi terpisah dalam pemanfaatan sumberdaya waktu akan sama, sama memanfaatkan sumberdaya waktu melebihi waktu produksi pada hari-hari biasa, pada kondisi ini sumberdaya waktu yang digunakan untuk aktivitas produksi adalah dari pukul 08.00 sampai pukul 16.00/hari, namun pada saat tertentu adanya faktor ekternal kedua tipologi pemanfaatan ruang rumah ini dapat memanfaatkan sumberdaya waktu 24 jam/hari.

Pemanfaatan rumah sebagai salah satu modal usaha memberikan kontribusi penting dalam pengembangan usaha karena selain dapat dijadikan sebagai tempat untuk tempat usaha juga digunakan sebagai hunian. Adapun alasan yang mendasari pengrajin memanfaatkan rumah untuk tempat usaha adalah mereka tidak mempunyai tempat lain yang dapat dijadikan sebagai tempat usaha serta rasa nyaman berada di rumah. Rumah dapat dijadikan sebagai wadah untuk tempat berkumpul dengan keluarga dan tempat usaha. Kaitannya dalam pemanfaatan rumah untuk kegiatan usaha diharapkan dapat meningkatkan produktifitas baik nilai tambah dalam uang maupun nilai produksi dalam kapasitasnya.

Usaha berbasis pada rumah (UBR) bertujuan untuk mendapatkan penghasilan keluarga atau ekonomi keluarga baik untuk penghasilan utama maupun sampingan. Sebagai sumber penghasilan, pekerjaan kerajinan batik ini merupakan penghasilan utama keluarga. Selain berdampak pada peningkatan penghasilan atau ekonomi pengrajin, kehadiran UBR telah mendorong terjadinya pengembangan rumah baik secara kualitas maupun kuantitas dengan tujuan pewadahan kegiatan UBR kerajinan batik tersebut lebih terjamin. Diagram pada Gambar 10 menunjukkan diagram keterkaitan tipologi rumah dengan perkembangan aktivitas usaha. 


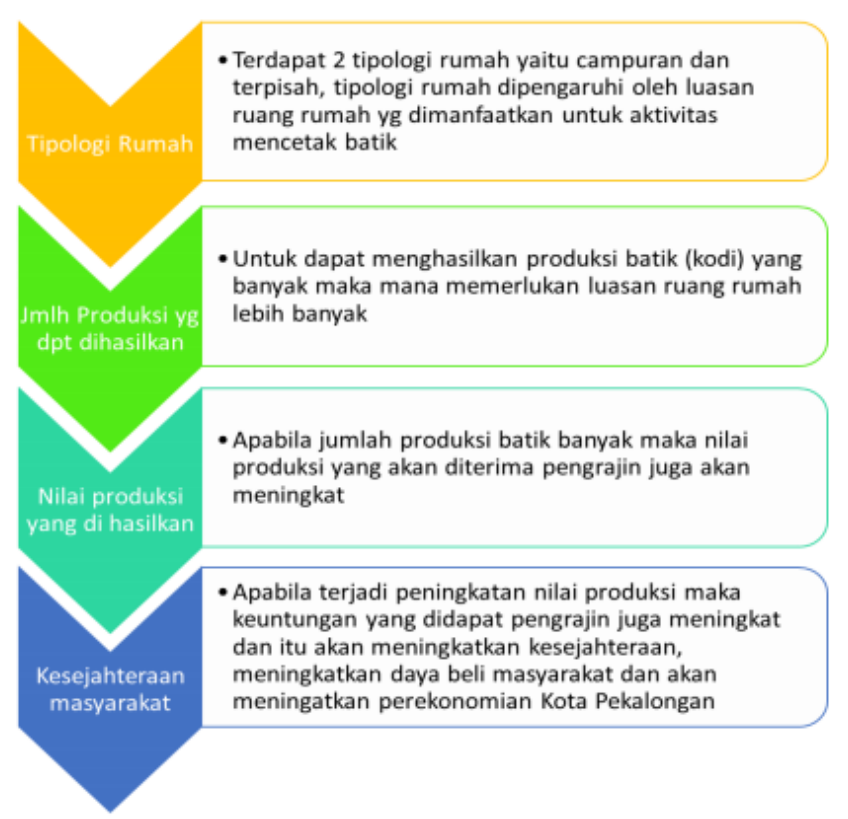

Gambar 10. Diagram Keterkaitan Tipologi Rumah dengan Perkembangan Usaha

\section{Kesimpulan}

Pada Usaha Berbasis Rumah (UBR), seluruh ruang rumah dimanfaatkan untuk kegiatan pembatikan sehingga tidak terdapat ruang kosong yang tidak dimanfaatkan terutama pada saat produksi batik meningkat. Pada saat produksi tinggi, 90\% ruang rumah akan digunakan sebagai ruang kerja. Berdasarkan pemanfaatan ruang dalam rumah untuk aktivitas mencetak batik, dapat diklasifikasikan menjadi dua tipologi, yaitu tipologi ruang rumah campuran dan tipologi ruang rumah terpisah. Pada tipologi campuran, aktivitas mencetak membutuhkan ruang rumah di bangunan induk. Sedangkan pada tipologi terpisah, diperlukan ruang rumah disekitar bangunan induk tetapi masih menempel dengan bangunan induk untuk aktivitas mencetaknya. Pemanfaatan sumber daya ruang rumah pada dua tipologi tersebut mempengaruhi pemanfaatan sumber daya pada rumah lainnya, yaitu uang dan waktu. Pada tipologi rumah terpisah akan lebih banyak menghasilkan pendapatan (money). Pemanfaatan waktu pada tipologi ruang rumah campuran maupun tipologi rumah terpisah dalam pemanfaatan sumber daya waktu akan sama. Ini dikarenakan tingkat produktivitas pembatikan dan jenis proses pembatikan (abstrak, sablon/printing dan cap) yang akan mempengaruhi tipologi rumah dan pemanfaatan sumber daya pada rumah. Kondisi ini menunjukkan bahwa tingkat produktivitas pembatikan akan mempengaruhi jumlah ruang rumah yang dimanfaatkan, dan jenis proses pembatikan (abstrak, sablon/printing dan cap) akan mempengaruhi tipologi rumah dan pemanfaatan sumberdaya pada rumah.

\section{Daftar Pustaka}

Indeswari, A., Antariksa, Pangarsa, G. W., \& Wulandari, L. D. (2013). Pola ruang bersama pada permukiman Madura Medalungan di Dusun Baran Randugading. Jurnal RUAS, 11(1), 37-46.

Moleong, L. (2006). Metodologi Penelitian Kualitatif. Bandung: PT. Remaja Rosdakarya. 
188 Pola Pemanfaatan Ruang pada Usaha Berbasis Rumah (UBR) di Klaster Batik Jenggot ...

Silas, J. (2000). Rumah produktif, pendekatan tradisi dan masyarakat. Makalah disampaikan pada Seminar Rumah Produktif dalam Dimensi Tradisional dan Pemberdayaan dalam rangka Dies Natalis Arsitektur ITS ke-35, Institut Teknologi 10 November, Surabaya.

Strassman, B. I. (1987). Effects of cattle grazing and haying on wildlife conservation at National Wildlife Refuges in the United States. Environmental Management, 11(1), 35-44. doi:10.1007/BF01867177.

Tipple, A. G. \& Kellett, P. W. (2000). The home as workplace: A study of income generating activities within the domestic setting. Environment and Urbanization, 11(2), 203-214. doi:10.1177/095624780001200115.

Tipple, A. G. (2004). Settlement upgrading and homebased enterprises: Discussions from empirical data. Cities, 21(5), 371-379. doi:10.1016/j.cities.2004.07.006.

Tipple, A. G. (2005). The place of home-based enterprises in the informal sector: Evidence from Cochabamba, New Delhi, Surabaya and Pretoria. Urban Studies, 42(4), 611-632. doi: 10.1080/00420980500060178.

Turner, J. F. C. 1972. Housing by people: Towards autonomy in building envirtonments. London: A Marion Boyars Book.

Wibisono, I. (2013). Tingkat dan jenis perubahan fisik ruang dalam pada rumah produktif (UBR) perajin tempe Kampung Sanan, Malang. Jurnal RUAS, 11(1), 75-88. 